\title{
Kiterjedt acetabularis csontdefektusok (Paprosky 3B medence diszkontinuitással) kezelése impaktált csont allograft és ilioischialis cage használatával
}

\author{
DR. FRIEBERT GÁBOR, DR. GOMBÁR CSABA, DR. SISÁK KRISZTIÁN
}

\section{ÖSSZEFOGLALÁS}

A revíziós csípősebészet egyik legnagyobb kihívása a medence folytonosságának megszakadásával járó vápadefektusok kezelése. Az esetek túlnyomó részében a törés egy krónikus stressztörés, ami az elvékonyodott vápafenéken alakul ki, és általában egy haránt lefutású, az acetabulumot gyakorlatilag megfelező elváltozást jelent. A rutin röntgenfelvételeket ala és obturator felvételekkel, valamint CT-vel kiegészítve a diagnózis és a mútéti terv elkészíthető. Több mútéti megoldás létezik, és jelenleg nincs konszenzus az ideális megoldásról. Az alkalmazott megoldások közül a leggyakoribb négy, az úgynevezett cup-cage konstrukció, a magas porozitású vápabeültetés hátsó oszloplemezeléssel, az úgynevezett medence disztrakció és cement nélküli vápabeültetés, és a két vagy három füllel rendelkező (egyedi gyártással vagy anélkül készült) vápakosarak használata. Ezen technikák közös célja a vápa hosszú távú megbízható rögzítése mellett a diszkontinuitás gyógyulása (csontos vagy fibrosus módon). A szerzők 5 saját medence diszkontinuitás miatt impaktált csontgraft beültetéssel és vápakosár használatával kezelt eset kétéves klinikai és radiológiai utánkövetését mutatják be.

\section{Kulcsszavak: $\quad$ Acetabulum; Csípöprotézis; Csontdefektus; Csontgraft; Reoperáció;}

G. Friebert, Cs. Gombár, K. Sisák: Treatment of extensive acetabular bone defects (Paprosky $3 B$ with pelvic discontinuity) with the use of impaction bone grafting and ilioischial cage

The treatment of large acetabular defects with pelvic discontinuity remains one of the biggest challenges in revision hip surgery. In the majority of cases the discontinuity is a chronic transverse stress fracture of the acetabular floor, heavily compromised by osteolysis. Judet views and a CT scan compliment routine radiographs to establish the diagnosis and prepare the surgical plan. There are several surgical management options available, although there remains to be no consensus about the ideal one. The four most frequently utilised techniques, are the cup-cage construct, the use of high porosity cups with posterior column plating, the pelvic distraction with uncemented cup implantation and the use of two- or three-flanged (custom made or off the shelf) cages. The common aim of all these methods is to provide stable fixation for the acetabular component and to ideally achieve bony or fibrosus union of the compromised acetabular floor. The authors present their own 5 cases of pelvic discontinuity where impaction bone grafting and an antiprotrusion cage were used. A two year clinical radiological follow-up was performed.

Keywords: $\quad$ Acetabulum - Surgery; Allografts; Arthroplasty, replacement, hip; Bone diseases -Surgery; Bone transplantation - Methods; Hip Prosthesis; Reoperation; 


\section{BEVEZETÉS}

Az évről-évre végzett csípőprotézis revíziók száma az elmúlt két évtized során emelkedett (6). Az újgenerációs primer eszközök, kopófelszínek, illetve a nagy porozitású bioaktív felszínek kifejlesztésével az implantátumok kihordási ideje egyre hosszabbodik, de a mindennapi magyarországi ortopédiai gyakorlatban még mindig gyakran találkozunk elsősorban a vápakomponensek „idő előtti” elhasználódásával, kopásával, lazulásával. A kilazult, illetve kopott komponensek körül a terhelési erők eloszlása megváltozik, kopástermékek halmozódnak fel, helyi gyulladásos folyamatok aktiválódnak, ez progresszív csontfelszívódáshoz, végül nagyméretű hiányok kialakulásához vezethet (10). $A$ rendszeresen végzett kontrollvizsgálatokon a korai felismerés és beavatkozás szükségszerű, a csontállomány mennyiségének és minőségének megmentése, illetve a jó rekonstrukciós eredmény elérése szempontjából $(9,23)$. A fájdalom sok esetben késői tünet, így a ritka vagy rendszertelen kontroll miatt, gyakran már nagy vápadefektusokkal jelentkeznek az elhanyagolt betegek (10). A fent leírt krónikus folyamat végül akár minor trauma vagy inadekvát behatás következtében is stresszfraktúrához, csontos folytonosság megszakadásához vezethet. A teljes csípő endoprotézis (TEP) vápa komponens lazulás a revíziók leggyakoribb indikációja. A nagy csonthiánnyal, medence folytonosságának megszakadásával járó esetek előfordulása ritka (incidencia 0,9\%) (7), épp ezért alapos kivizsgálást, gondos mútéti tervezést igényelnek és a legösszetettebb technikai kihívást jelentik $(4,20)$.

A mútéti tervezés alapját a röntgendiagnosztika adja. A súlyos periprotetikus vápadefektusok pontos feltérképezéséhez a rutin kétirányú (anteroposterior (AP) és oldal-) felvételek elégtelenek. Ezeket Judet szerint készült ferde (obturator és iliaca oblique) irányokkal szükséges kiegészíteni. Ezek alapján közel pontos klasszifikáció adható a vápakomponens körüli csontdefektusról. A legelterjedtebben alkalmazott besorolás a Paprosky és munkatársai által kidolgozott rendszer, amely egy validált, reprodukálható és a megfelelő mútéti technika megválasztására is alkalmazható rendszer (18, 19, 29). A hagyományos radiológiai elemzés csupán 40-70\%-os szenzitivitással rendelkezik a periprotetikus vápadefektusok esetében. Még több aspektusból készült felvételeken is lehetnek a fém komponensek által kitakart területek. A preoperatívan készült computer tomográfiás (CT) felvételekkel pontosabb kép és háromdimenziós (3D) rekonstrukció nyerhető az acetabulum defektusairól, szenzitivitása 74-98\% (10) (1. ábra).

A Paprosky 3B periprotetikus defektusok esetében a vápakomponens medio-cranialis irányban vándorol. Ezzel együtt nem csak kavitális defektus, hanem a csontos medence szegmentális hiánya is kialakul. Ez végül az acetabulum, így a teljes medencefél haránt irányú szétválásával szövődhet (2. ábra). A medence diszkontinuitással járó Paprosky 3B defektusok megoldására "gold standard", minden esetben jó eredménnyel alkalmazható módszer nincs. A kidolgozott protézisrendszerek sikeres alkalmazhatóságát befolyásolja a megmaradt csontállomány mennyisége, minősége, biológiai kapacitása és gyógyhajlama. Ezek meghatározása nem mindig egyszerű feladat. Igen súlyos esetekben a nagy szférikus „Jumbo” vápákkal és a cup-cage rendszerekkel primer stabilitás nem érhető el a szegmentális defektusok miatt, mivel gyakran nincs olyan félgömb részlet, ami legalább 50\%-ban megtámasztja a revíziós vápakomponenst (22). Kiterjedt csonthiányok esetén jól alkalmazható disztrakciós technika trabecular metal (TM) augmentekkel kiegészítve, amennyiben a megmaradt csontállomány több irányban is alkalmas csavaros rögzítésre. Bizonyos esetekben a csontos vápa csupán egy papírvékony kortikális csontkarima, a csontintegrációs potenciál elégtelen és a csavaros fixáció sem lehetséges. Legtöbb esetben a hátsó vápaszél még igen nagy hiányok esetén is képes támasztó funkció betöltésére. Ezt kihasználva egyedi, a defektust átívelő, hátsó oszlopra támaszkodó és az iliumba, az ischiumba, illetve az os pubisba csavarokkal rögzíthető, szférikus antiprotrusiós vápakosarak (antiprotrusion cage - APC) alkalmazhatók. Legyártásuk 3D CT rekonstrukció alapján időigényes, költséges folyamat. Beültetésükhöz nagy feltárás szükséges, hogy az ép, csavaros rögzítésre alkalmas csontfelszínek elérhetők legyenek. Erre a posterolateralis feltárás alkalmas, amellyel a hátsó vápaszél, az ilium és az ischium is jól megközelíthető. A környező kavitális csonthiányok feltölthetők 
TM augmentekkel, vagy csontgrafttal. Végül a stabilan beültetett vápakosárba kerül becementezésre a tényleges polietilén vápa (1). Az egyedi vápakosarak elvét képviselik, de könynyebben elérhető megoldást adnak a sorozatgyártott úgynevezett bi- vagy tri-flange vápakosarak. Rögzítésük a vápadefektuson túl, az ép iliumban és ischiumban történik. Felszínüket legtöbb esetben bioaktív anyag (hidroxy-apatit vagy porózus titán) fedi, mely jobb cage-graft fixációt eredményez. A csontgraft használatának előnye, hogy a medence csontos folytonosságát állítja helyre. Jó átépülést követően a későbbi revíziók tervezésekor a komponensválasztást megkönnyítheti.
Munkánk célja az évtizedek során kifejlesztett számos csípőprotézis vápa revíziós technika közül egy összetett módszer bemutatása, a klinikánkon operált, saját esetek elemzésén keresztül. A Protrusio Cage és impaktált csontgraft beültetésével a súlyos, aszeptikus lazulásos (Paprosky 3B), a medence csontos folytonosságának megszakadásával járó esetek, stabil, jól terhelhető rendszer létrehozásával és a csontállomány rekonstrukciójával kezelhetők. Emellett kiemeljük a rendszeres és módszeresen végzett utánkövetés fontosságát az implantátumok késői mechanikai szövődményeinek időben történő felismerésében és kezelésében.

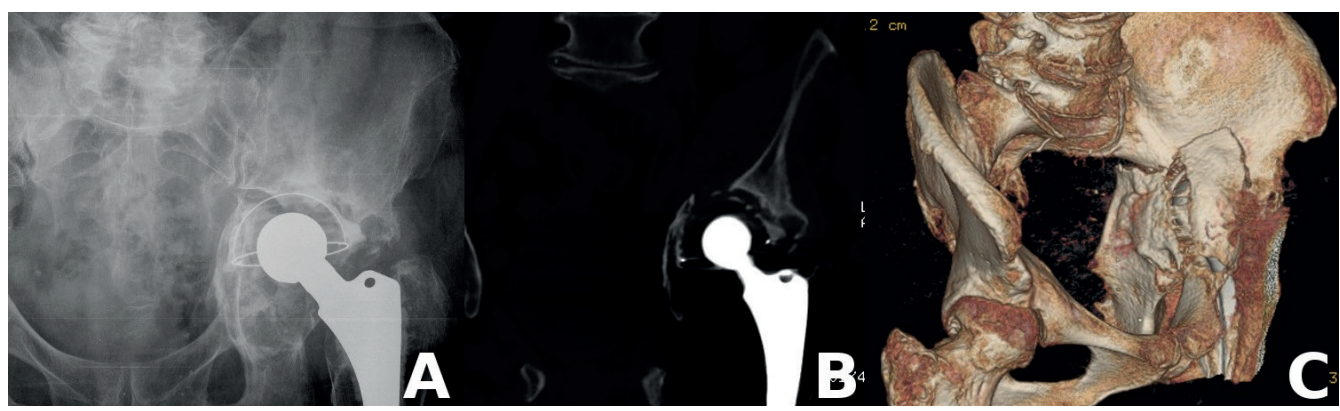

1. ábra

Mütét elötti diagnosztikus képek:

A: AP röntgenfelvételen már jól látható a vápa medio-cranialis vándorlása és a medence folytonosságának megszakadása;

B: CT képen a vápafenék betört, a vápa a medencébe protrudált;

C: 3D CT rekonstrukción is jól látható a folytonosság megszakadása, a tört darabok elhelyezkedése.

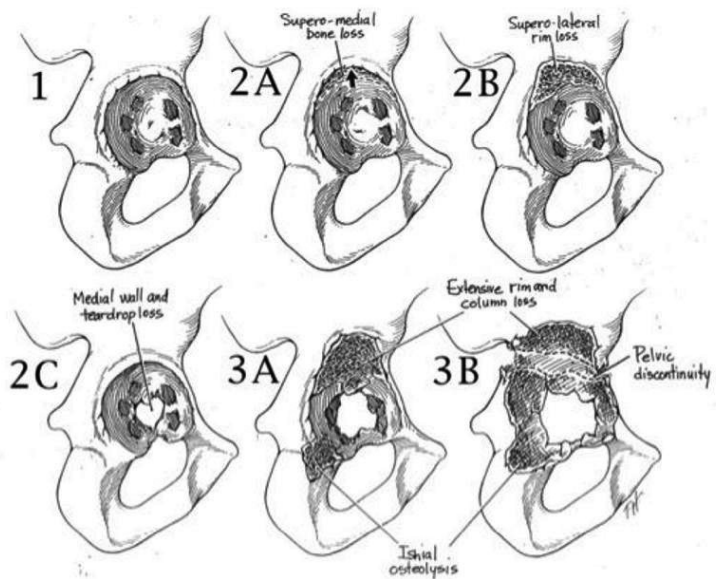

2. ábra

A periprotetikus medencedefektusokat osztályozó Paprosky-klasszifikáció. A 3B ábrán látható a lehetséges medencediszkontinuitás típusos elhelyezkedése (3). 


\section{ANYAG ÉS MÓDSZER}

\section{Betegszelekció}

Retrospektív vizsgálatunkba a klinikánkon 2016-2017 között medence diszkontinuitás miatt APC (DePuy Protrusio Cage - DePuy Orthopaedics, Inc, Warsaw, IN) és csontgraft beültetésével operált betegeinket vontuk be. A diszkontinuitás oka a vápakomponens aszeptikus lazulása, vagy adekvát traumára már lazult komponens körül létrejött, medencefolytonosság megszakadásával járó vápafenéktörés volt.

\section{Preoperativ diagnosztika}

A periprotetikus medence diszkontinuitás sikeres ellátásának legfontosabb alappillére az alapos preoperatív diagnosztika és tervezés. Preoperatív röntgen- és CT felvételeken elvégeztük a vápadefektusok Paprosky-szerinti klasszifikálását, a vápakosár beültetés indikációjaként, amit a mútéti lelet is megerősített (2. ábra). A 3D CT segítségével meghatározható volt a választandó APC hozzávetőleges nagysága, szükséges allograft mennyisége, és a csavaros rögzítésre alkalmas csontterületek elhelyezkedése (10).

\section{Mútéti technika és eszközök}

A váparevíziót minden esetben oldalfekvő pozícióban, hátsó feltárásból végeztük a korábbi feltárás vagy feltárások típusától függetlenül. A kilazult vápa eltávolítását követően a benőtt sarjszövetet mind a csontfelszínekről, mind a krónikus törtvégekről alaposan eltávolítjuk. A mútét során meghatározott vápakosárhelyzetnek megfelelően a csontfelszíneket felmarjuk úgy, hogy a lehető legnagyobb vitális csontfelszínt kapjuk a beültetéshez, így érhető el a legjobb biológiai beépülési potenciál. A vápakosár próbájának, a végleges APC beültetéséhez és minél nagyobb implantátum, csontkontaktushoz, az acetabulum hátsó oszlopát kipreparáljuk, az ischiumot, valamint az ilium proximalis részét feltárva $(1,2,7,20)$ (3. ábra).

A csonthiányos területeket liofilezett, homológ „spongiosa chips”-szel feltöltjük, a graftot amennyire a meggyengült, gyakran pergamenszerű csontállomány engedi, impaktáljuk. Így a defektus méretét valamelyest csökkentjük és szegmentális hiány mellett észlelhető kavitális defektusokat kitöltjük, megadva a lehetőséget a csontos integrációra a terhelési viszonyok rendezését követően. A megfelelő méretű vápakosár próbát először a hátsó vápaperemhez illesztjük, a füleit, a csontos anatómiának megfelelően modelláljuk. Ezt követően a végleges, a próbának megfelelő méretű APC-t szintén modelláljuk és először a füleit az iliumhoz és az ischiumhoz rögzítjük, melyet transacetabuláris csavarokkal egészítünk ki (4. ábra). Ezzel a technikával csökkenthetők a fülek tövénél ható deformáló erők, így a komponenstörés kockázata (28). Megfelelő primer stabilitás elérését követően polietilén vápát cementezünk be különösen figyelve a méretezésre és figyelembe véve a megfelelő meredekséget és anteverziót (6) (5. ábra).

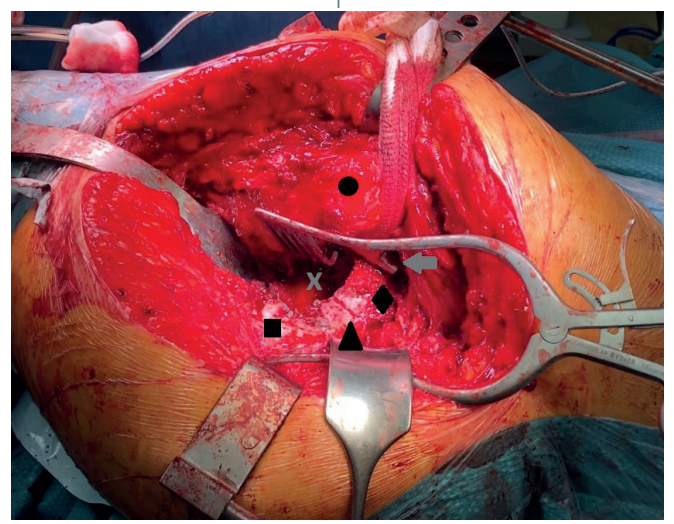

\section{3. ábra}

Hátsó feltárás, a femurt (•) a protézisnyaknál $(\leftarrow)$ fogva ventral felé elemelve jól látható az előkészített vápa (x), annak hátsó pereme, a folytonosság megszakadása (-), illetve a csavaros rögzítéshez feltárt és előkészített ilium (\$) és ischium (ロ). 


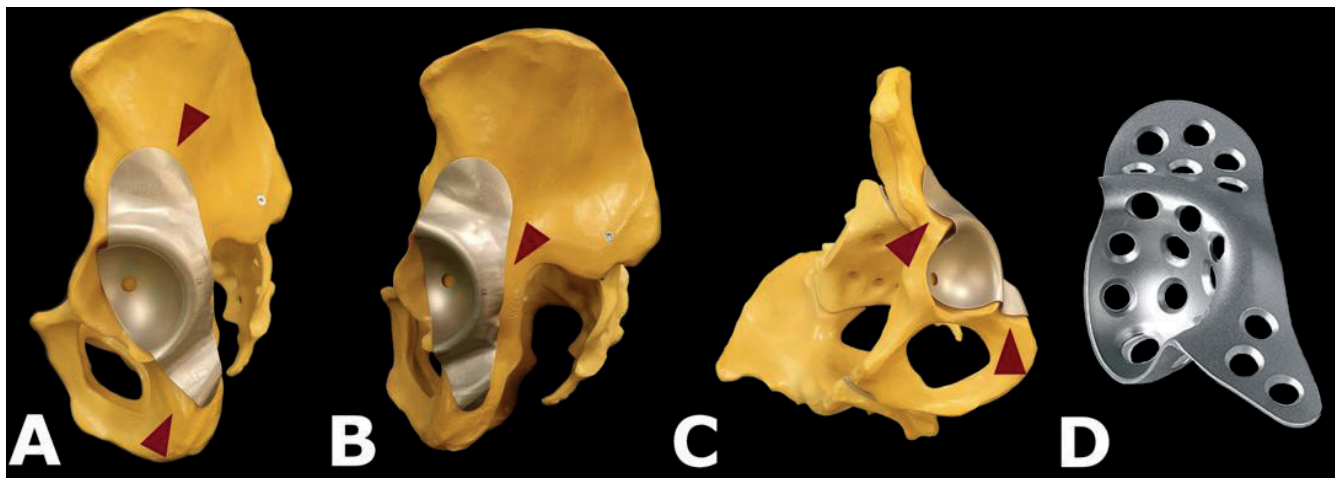

4. ábra

A vápakosár komponenssel megegyező méretü, modellálható alumínium próba eszköz „száraz modellje” látható. A és B: Az eszköz a vápadefektust áthidalja, az iliumon, az ischiumon és a hátsó oszlopon támaszkodik ( - ); C: Jól látható, hogy az eszköz teljesen kitölti a vápát, szárnyai modellálást követöen az iliumra és az ischiumra tökéletesen illeszkednek ( - ); D: Jól látható, hogy a próba formájában csak a csavaros fixálásra kialakított lyukak hiányában tér el a végleges komponenstöl.

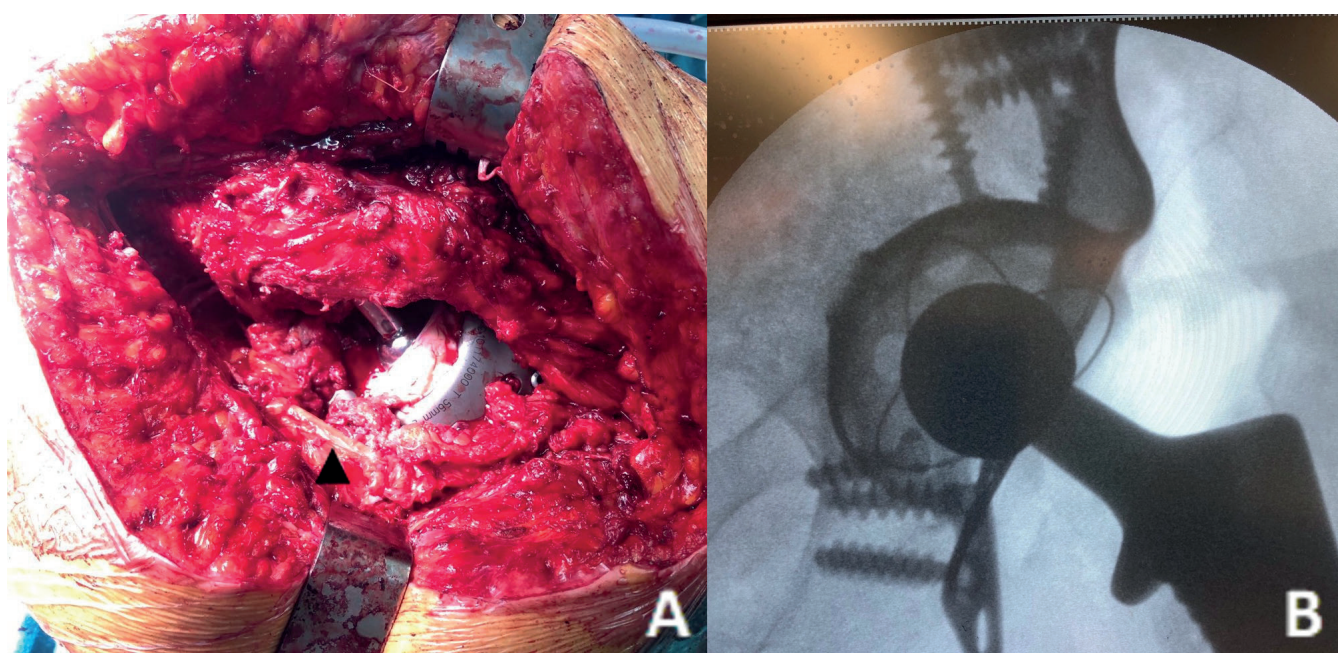

\section{5. ábra}

A: Hátsó feltárásból végzett revízió, a femurt ventral felé elemelve jól látható a végleges vápakosár és a becementezett polietilén vápa. $N$. ischiadicus (-).

B: A végleges protézis röntgenképe. A mütét során minden komponens és csavar elhelyezkedését képerősítővel ellenörizzük.

\section{Posztoperativ rehabilitáció}

A mútétet követően az alábbi rehabilitációs protokollt alkalmaztuk, figyelembe véve a csontgraft és az osteosynthesis tehermentesítését. $\mathrm{Az}$ első 48 órában megkezdtük az operált ízület gyógytornász vezette passzív tornáztatását. Majd aktív torna indult és a 8 . posztoperatív hétig segédeszköz használatával az operált végtag terhelését csak talpérintéssel engedélyeztük (15-20 kg-os részterhelésnek felel meg). Az első radiológiai kontrollt követően, a terhelés hetente 10-15 kg-os növelésével fokozatosan terheltettük a csípót. 
A 15. posztoperatív héttől engedtük a végtag teljes testsúllyal terhelését és a segédeszközök fokozatos, igény szerinti elhagyását.

\section{Adatgyüjtés}

A demográfiai adatok (nem, kor, testsúly, testmagasság, BMI, revíziók száma, a korábbi vápakomponens túlélési ideje, mútéti indikáció) mellett, az operatív adatokat (mútét hossza, anesztézia típusa, beültetett komponensek mérete, csavarok száma és elhelyezkedése, mútéti vérvesztés) és a posztoperativ eseményeket (perioperatív vérvesztés mértéke, transzfúziós igény és mennyisége, osztályos tartózkodás hossza) is feljegyeztük. E mellett külön hangsúlyt fektettünk a korai és késői szövődmények adminisztrálására.

\section{Követési stratégia}

Betegeinket minimum két éven át követtük. A kontrollvizsgálatokat a mútét utáni 6 . héten, a 3., illetve 6 . hónapokban, egy évvel a mútétet követően, majd évente végeztük.

\section{Klinikai állapot felmérése}

Minden vizit alkalmával megtörtént a rutin fizikális vizsgálat, amit az Oxford Hip Score (OHS) és Visual Analog Scale (VAS) skálák önértékelő tesztjeivel egészítettünk ki, illetve feljegyeztük a segédeszköz szükségletet.

\section{Radiológiai követés}

Radiológiai kontroll minden alkalommal készült, kétirányú csípő- és AP medencefelvételek formájában. Méréseinket a symphysisre centrált $\mathrm{AP}$ medence felvételeken végeztük. $A$ mért értékeket az ismert átmérőjű protézis fej komponens valós/kép arányával korrigáltuk. A medence csontdefektus minden esetben súlyosan érintette a Köhler-vonalat (Sutherlandmódszer) (12), így e helyett az obturator vonalhoz viszonyítva határoztuk meg a vápakosár vertikális, horizontális elhelyezkedését és a vápakosár dőlési szögét (27) (6. ábra). A kontrollok során kapott eredményeket összehasonlítottuk az egyes időpontokban az eszköz stabilitását vizsgálva. Maximum $5 \mathrm{~mm}$-es, illetve $5^{\circ}$-os elmozdulási hibahatárt alkalmaztunk a felvételeken előforduló nagyítási és expozíciós különbségek miatt. Stabilitási vizsgálatok során feljegyeztük a csavarok lazulását/elmozdulását is, illetve vizsgáltuk a csavarok körüli csontfelszívódást, minimum 2 mm-es radiolucens sávok megjelenését. A beültetett csontgraft átépülését, illetve felszívódását a graft-cage határon DeLee-Charnley I-III zónákban és a graft-host határokon vizsgáltuk. A beépülés biztos jeleként a graftban trabekulumok, a felszívódás biztos jelének minimum $2 \mathrm{~mm}$-es radiolucens sávok megjelenését vettük (11). Ochs és munkatársai munkája alapján $5 \mathrm{~mm}$, illetve $5^{\circ}$ fölötti komponens vagy csavar elmozdulást, csavartörést, progresszív graftfelszívódást a lazulás biztos jeleként vettük (17).

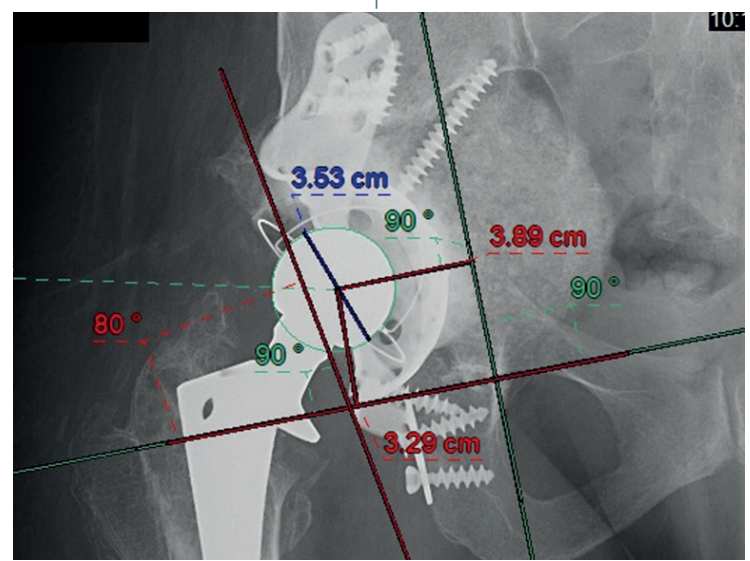

6. ábra

Mútét utáni AP röntgenfelvétel, amelyen mérési módszerünk látható: Kék vonal: Fejátmérő (ismert paraméter), ennek viszonyításával kiküszöbölhető a különböző idöpontban készült röntgenfelvételek közötti nagyítási különbség. Zöld vonal: Obturator vonal és a ráhúzott meröleges, ehhez viszonyítjuk a forgásközéppont helyzetét. Piros vonal: A forgásközéppont vertikális és horizontális elhelyezkedése, illetve a vápakosár meredeksége. 


\section{Kizárási kritériumok}

A vizsgálatba nem vontuk be azokat a betegeket, akiknél a preoperatív radiológiai leletek vagy a mútéti lelet kizárták a vápakomponens körüli súlyos Paprosky 3B fokú aszeptikus lazulást és medence folytonosságának megszakadását, illetve más eszközökkel és eltérő módszerekkel végzett revíziókat.

\section{EREDMÉNYEK}

Vizsgálatunkba eddig 5 esetet válogattunk be, amelyek mindegyike nő, átlagéletkoruk a mútét időpontjában 68 év (53-76 év), Body Mass Index (BMI) átlag: $27,5 \mathrm{~kg} / \mathrm{m}^{2}$ (min.: $23,7 \mathrm{~kg} / \mathrm{m}^{2}$, max.: $29,4 \mathrm{~kg} / \mathrm{m}^{2}$ ) volt. Minden esetben röntgenvizsgálattal Paprosky 3B típusú acetabularis defektust diagnosztizáltunk medence diszkontinuitással, amelyet 3D CT rekonstrukcióval igazoltunk, mútéti lelettel megerősítettünk. Az APC vápakosárral történő revíziót két esetben első, két esetben második és egy esetben harmadik revíziós mútétként végeztük. Négy esetben a vápakomponens aszeptikus lazulása, míg egy esetben a lazult komponenst érő alacsony energiájú trauma következtében kialakult törés okozta a medence folytonosságának megszakadását. Aszeptikus lazulásos esetekben az előzőleg primeren vagy már egy korábbi revízió során beültetett vápa komponensek átlagos túlélése 114 hónap volt (5-196 hónap). A mútétek átlagos hossza 172 perc volt (160-180 perc). Szárrevízió egy esetben sem történt. A defektusok feltöltését homológ „spongiosa chips” impaktálásával végeztük. A csontdefektusok méretének megfelelően 2-7 felezett, liofilezett combfej graftot használtunk fel. A vápakosár rögzítése 3 esetben 7, egy-egy esetben 6 és 8 darab csavarral történt. A mútéti tervezés során, a készült CT felvételek segítségével az egyéni csontviszonyoktól függően terveztük meg a csavarok helyzetét. Egy vagy kettő csavar transacetabularisan került elhelyezésre. A hosszú, közel háromórás mútétek során az átlagos vérvesztés $480 \mathrm{ml}(300-700 \mathrm{ml})$ volt. $\mathrm{Az}$ osztályos tartózkodás alatt rendszeres laborkontrollt végeztünk. Két esetben került sor transzfúzióra, a többi esetben a vérkép paraméterek a kezdeti esést követően stabilak maradtak, illetve a betegek objektív és szubjektív klinikai állapota (major hypoxiás tünetek hiánya) nem indokolta a vértranszfúzió adását. Az egyik transzfúziós esetben (4. beteg) a transzfúziót 2 egység vörösvérsejt (vvs.) koncentrátummal a késői posztoperatív napokon végeztük, folyamatos haemoglobin (hgb.) esés miatt, illetve itt tapasztaltuk a mútétet követő leghosszabb hospitalizációs időszakot is (23 nap). A másik esetben (5. beteg) már a műtőben 2 egység vvs. koncentrátum adása történt, amit az 5. posztoperatív napon folyamatos hgb. esés miatt ismételtünk. Ebben az esetben a mütétet követően osztályon eltöltött napok száma 11 volt. Ezt a beteget (5. beteg), ahol már a mútét során transzfúzióra került sor kizártuk a perioperatív vérvesztéssel kapcsolatos elemzéseinkből. Az 1-4. beteg hgb. esése átlagosan $44 \mathrm{~g} / \mathrm{l}(33-51 \mathrm{~g} / \mathrm{l})$. Mind a négy esetben jelentős mértékű, több mint $20 \mathrm{~g} / \mathrm{l}$ hgb. csökkenést észleltünk. A teljes perioperatív vérvesztés mértékét (haematocrit (htc.) drop) a Nadler-formula segítségével számítottunk (8). Az 1-4. beteg átlag vérvesztése 1,7 liter $(1,3-2,21)$, kiugró értéket nem tapasztaltunk $(\sigma=0,413)$. A posztoperatív hospitalizáció átlaga 13 nap (8-23 nap) (I. táblázat).

A rendszeres kontrollvizsgálatokat a mútétet követően 3, 6 hónappal, 1 és 2 évvel végeztük. A minimum utánkövetési idő 24 hónap. Radiológiai követéssel a graft-host határokon kielégítő átépülést, illetve trabekularizálódást észleltünk. Minden esetben kielégítő vápakosár-graft és vápakosár-host kontaktust észleltünk (7. ábra). Graft felszívódás nem történt. Csavarlazulást két esetben találtunk az os ischiiben, az eszköz stabilitását nem befolyásolta (8. ábra). A vápakosarak migrációját egy oldali, csípőre fókuszált AP felvételeken vizsgáltuk. Hibahatárt meghaladó horizontális (5 mm), vertikális elmozdulást $(5 \mathrm{~mm})$, rotációt $\left(5^{\circ}\right)$ egy esetben sem észleltünk (17).

A klinikai állapot felmérésére kitöltött OHS kérdőíveket kiértékelve, a mútét előtti átlag pontszám 10 (3-16), az utolsó kontroll átlaga: 29 (24-32). A VAS skálán jelzett pontértékek a mútét előtt átlagosan 8 pont (5-10), míg az utolsó kontroll alkalmával átlagosan 3 pont (0-7). Mind a VAS, mind az OHS tesztek eredményei minden betegnél pozitív irányú tendenciát mutattak (9. ábra).

$\mathrm{Az}$ utolsó kontrollvizsgálatra két beteg 
járóbottal, három beteg pedig segédeszköz nélkül érkezett. A korábban említett vérzéses szövődményeken kívül még egy esetben tapasztaltunk a mútéti területen szövődményt. Itt elhúzódó sebgyógyulás és seromás váladékozás jelentkezett, emiatt az ismételt osztályos felvételre további megfigyelés és rendszeres kötéscsere igénye miatt volt szükség. A seromából nyert minta mikrobiológiai vizsgálata negatív eredményt adott. $A z$ alkalmazott terápia hatására a tünetek szűntek, sebe rendben gyógyult. A követési szakban egy esetben sem volt szükség re-operációra.

I. táblázat: A vizsgált betegek demográfiai és perioperatív adatai

\begin{tabular}{|c|c|}
\hline Nem & 5 nő beteg \\
\hline Indikáció & Paprosky 3B + medence diszkontinuitás \\
\hline Aszeptikus Lazulás & 4 \\
\hline Periprotetikus Törés & 1 \\
\hline \multicolumn{2}{|l|}{ Revízió száma } \\
\hline 1. & 2 \\
\hline 2. & 2 \\
\hline 3. & 1 \\
\hline Átlag életkor: & 68 év (53-76) \\
\hline Átlag BMI: & $27,5 \mathrm{~kg} / \mathrm{m} 2(23,7-29,4)$ \\
\hline \multicolumn{2}{|l|}{ Előző komponens: } \\
\hline Primer cementes vápa & 2 \\
\hline Revíziós cement nélküli vápa & 2 \\
\hline Single flange cage & 1 \\
\hline Előző komponens túlélése: & 114 hónap (5-196) \\
\hline Átlag mútéti vérzés: & $480 \mathrm{ml}(300-700)$ \\
\hline Transzfúzió: & 2 esetben \\
\hline Átlag Hgb esés (4): & $44 \mathrm{~g} / \mathrm{l}(33-51)$ \\
\hline Átlag Htc esés (4) (Nadler): & $1,7 \mid(1,3-2,2)$ \\
\hline Átlag hospitalizáció: & 13 nap (8-23) \\
\hline
\end{tabular}




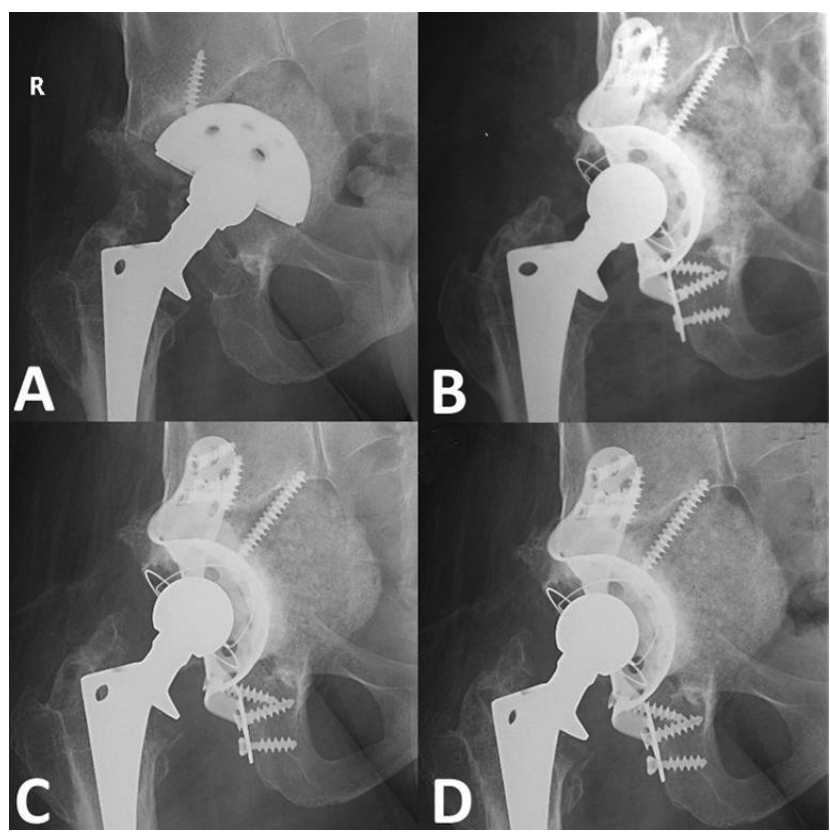

\section{7. ábra}

A: Revizió elötti felvételen a korábban beültetett revíziós vápa malpozíciója, a rögzítőcsavar törése látható; B: Közvetlen mütét utáni kontroll röntgenfelvétel;

C: Féléves kontroll röntgen;

D: Kétéves kontroll röntgen;

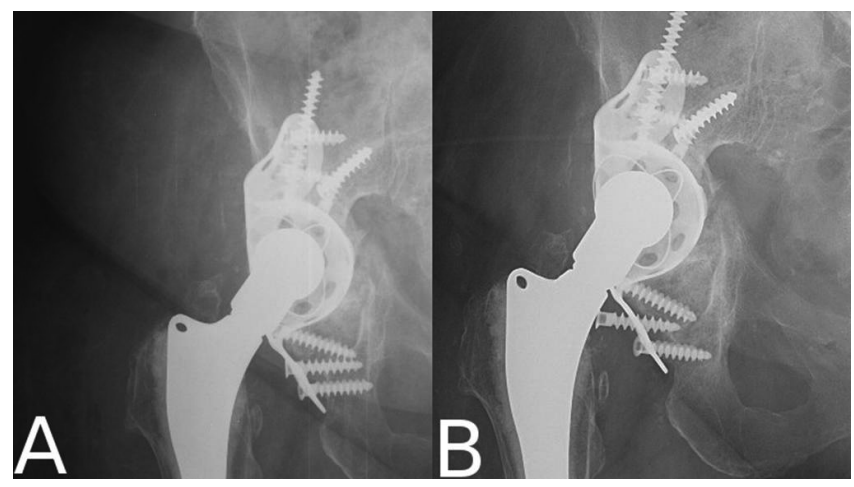

\section{8. ábra}

A: Mütét utáni első röntgenkontroll.

B: Féléves kontroll röntgenfelvétel, az ischiumban jól látható csavarlazulás, a protézis helyzete változatlan, stabil eszköz látható. 


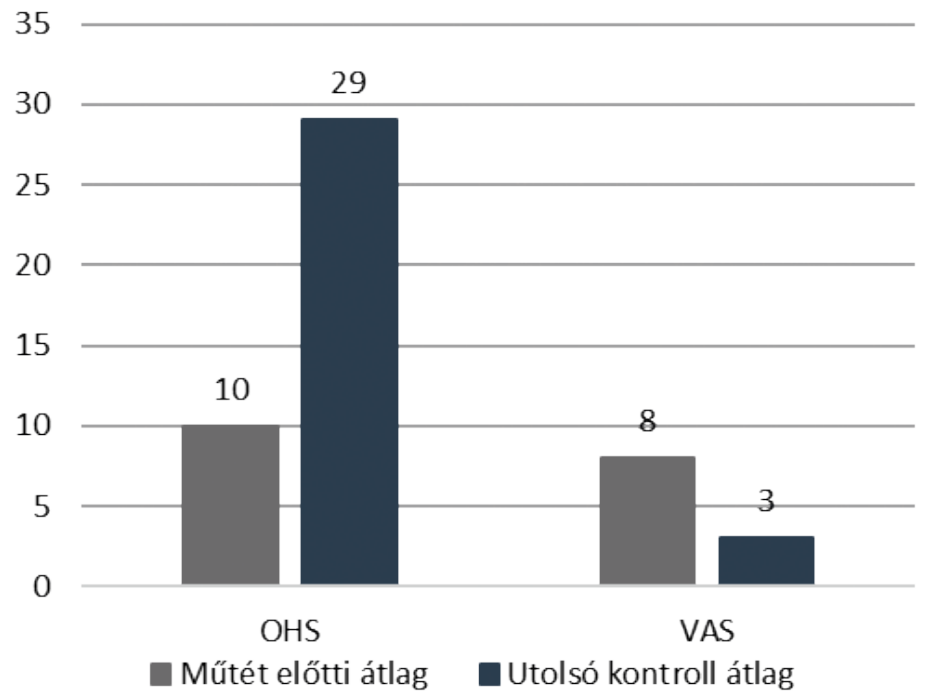

9. ábra

OHS és VAS tesztek átlagai a mütét elött és az utolsó kontroll alkalmával

\section{MEGBESZÉLÉS}

Súlyos, a medence folytonosság megszakadásával is járó teljes csípőprotézis vápakomponens körüli, Paprosky 3B csonthiányok mútéti megoldása az alapos képi diagnosztikán és preoperatív tervezésen alapszik. Ennek fontos részei a többirányú, jó minőségű röntgenfelvételek és a CT vizsgálat, illetve a belőle készült 3D rekonstrukciós képek. Fontos, hogy „gold standard" eljárás hiányában a legmegfelelőbb revíziós eszközök kiválasztása ezek, illetve a rendelkezésre álló technikai és szakmai/ gyakorlati feltételek alapján történjen. Mivel a súlyosabb defektusok összetett, akár több technika kombinált alkalmazását is igénylik, a mútétet megelőzően az alapos tervezés elengedhetetlen a stabil, jól terhelhető rendszer kialakítása érdekében.

Rövid távú, kis elemszámmal bíró vizsgálatunk alátámasztja, hogy az igen súlyos medence diszkontinuitással járó Paprosky 3B periprotetikus csontdefektusok ilioischialis cage és impaktált spongiosa allograft együttes használatával kezelhetők. Stabil, jól terhelhető rendszer hozható létre.

$\mathrm{Az}$ impaktált spongiosa graft minden esetben átépülést mutatott, felszívódást nem észleltünk. Kawanabe és munkatársai tanulmánya biomechanikai vizsgálatokkal támasztotta alá, hogy a különböző váparekonstrukciós eszközök sínező, és a pótlásban keletkező stresszerőket csökkentő funkciója a graftok összeesését megakadályozza, az átépülést elősegíti $(13,26)$.

Wedemeyer és munkatársai strukturális és impaktált allograft átépülését vizsgálták munkájuk során. 36 revíziót végeztek Paprosky $2 \mathrm{C}-3 \mathrm{~A}-3 \mathrm{~B}$ típusú vápadefektussal diagnosztizált betegen. 84,2 hónapos utánkövetési idő alatt csupán két esetben volt szükség a graft felszívódása és klinikai panaszok miatt re-revízióra (27).

$\mathrm{Az}$ utánkövetés során tapasztalt ischialis csavarlazulások ugyan az eszközök stabilitását nem befolyásolták, de a környező lágyrészképleteket (n. ischiadicus) hosszú távon irritálva panaszokat okozhatnak. Ennek elkerülése más típusú eszközök, mint a Burch-Schneider Cage (BSC) használatával lehetséges. A BSC ischiumban rögzülő szárnya modulálható, rögzítése a csontba vágott horonyban történik, cserébe a primer stabilitásuk kevésbé kiszámítható, mert a gyakran lítikus ischiumba kerül a háromszög formájú distalis vég, ahol csak korlátozott megtámasztást ad.

Regis és munkatársai kutatásuk során 56 Paprosky 3A, illetve 3B defektus miatt vápacserén átesett beteg átlag 11,7 éves 
utánkövetését végezték. A revízió során BSChomograft beültetés történt. 49 esetben jó graft átépülést tapasztaltak, az összesített túlélési ráta pedig $87,5 \%(21)$.

Berry és munkatársai 42 súlyos acetabularis csonthiánnyal kezelt eset 11 éves utánkövetéses vizsgálata során 76\%-os túlélést írtak le BSC és csontgraft használatával (5).

Hsu és munkatársai munkájukban 31 súlyos Paprosky 3A és 3B típusú csontdefektussal diagnosztizált beteg utánkövetését végezték. Átlag 5,5 év után ugyancsak 76\%-os BSChomograft kompozit túlélést írtak le (11).

A BSC graft-/host-csont felőli felszínén bioaktív, hidroxiapatit (HA) felszínkialakítás az eszköz csontos integrációját segíti. Míg az általunk alkalmazott Depuy Protrusio Cage „gyenge" tulajdonsága, hogy ilyen felszínkialakítást nem kapott. Ennek ellenére grafttal, illetve a host-csonttal érintkező felszíneken csontfelszívódást vagy támasztó felületvesztést nem észleltünk.

A biobanki graftokkal a medence csontos folytonossága helyreállítható, így a defektus mérete csökkenthető, az esetleges későbbi revíziók egyszerűbb technikákkal is elvégezhetők. Hátránya, hogy fertőzések, betegségek átvihetők, a revaszkularizáció és az átépülés zavart szenvedhet, a donorcsont felszívódhat. A TM augmentek használatával mindez elkerülhető (6).

López-Torres és munkatársai TM rendszer és BSC-graft kompozit csoportok összehasonlítását végezték. 84 eset 7,5 éves vizsgálata során nem találtak szignifikáns különbséget az infekciós és re-revíziós rátában, illetve a csont átépülés tekintetében. Ellenben a klinikai vizsgálatok szerint a TM csoportban kevesebb beteg igényelt segédeszközt, szubjektív önértékelő tesztekben magasabb pontszámot értek el, illetve magasabb elégedettségi rátát jegyeztek (14).

Migaud és munkatársai 2019-ben készült TM és BSC-graft revíziós rendszereket összehasonlító összefoglalójában kiemeli, hogy az évtizedek óta alkalmazott BSC-graft technika Paprosky $3 \mathrm{~A}$ defektusok esetén, 18 év után 85\%-os túlélési rátával rendelkezik. Csontfelszívódást a jó eredményeket adó eszközök környezetében is észleltek 10 év után. A TM rendszerek vizsgálatai $90 \%$ fölötti túlélést mutatnak, de a 10 éves követési időt még nem haladják meg. Infekciós ráta a TM rendszernél 4,9\%, míg az APC-k esetén 3,3\%. Szeptikus szövődmény esetén a TM komponensek eltávolítása nehézkes lehet, és nemkívánatos csontvesztéssel járhat. A Mayo Klinika ajánlása súlyos, diszkontinuitással járó vápadefektusok kezelésére az „a la carte rekonstrukció” moduláris TM komponensekkel („pelvic distraction”). A TM rendszerek viszont jóval drágábbak. TM komponensek használatát főleg APC-graft revíziót követően csont átépülési zavar, graftfelszívódás esetén javasolja a szerző (15).

Szczepanski és munkatársai 2019-ben publikált meta-analízise a medencediszkontinuitás kezelésében a fentebb már leírt 4 kezelési technikát vizsgálja a mechanikai szövődmények szemszögéből rövid, közép és hosszútávon. Összesített túlélés tekintetében az egyedi vápakosarak (5\%) és a cup-cage (7\%) alacsonyabb szövődményrátát adtak, mint a TM rendszerek (12\%) és a legrosszabb eredményt adó APC-k (24\%). Eredményeiket limitálja, hogy az APC-k rendelkeznek a leghosszabb, a legjobban dokumentált és legtöbb beteget vizsgáló utánkövetésekkel (24).

Rossman és munkatársai a törtvégek egyesítésére strukturális és impaktált graftot alkalmaztak, melyet a GAP II cage (Stryker) használatával fixáltak a medencéhez. Ötéves betegkövetésük során 87,8\%-os vápakosár revízió nélküli túlélést írtak le (22).

\section{KÖVETKEZTETÉS}

A medence folytonosság megszakadásával járó súlyos periprotetikus, acetabularis csonthiányok megoldása alapos preoperatív diagnosztikát és tervezést igényelnek. Megoldásuk az egyik legnagyobb kihívást jelenti az ortopéd sebészek számára. Az antiprotrúziós vápakosár és impaktált allogén csontgraft használatával stabil, jól terhelhető rendszer hozható létre, a medence csontos folytonossága helyreállítható. Még a legsúlyosabb csonthiányos defektusok esetén is alkalmazható, amikor a TM augmentátumok és cup-cage konstrukciók stabil beültetéséhez nem áll rendelkezésre megfelelő csontállomány. Az ízületi mozgás és a végtaghossz megőrzésére irányuló kényszerū megoldásként használható technika.

Mindennapi gyakorlatot és sebészi döntést befolyásoló eredményekhez, illetve statisztikai 
elemzésekre alkalmas adatokhoz nagyságrendekkel több beteg bevonása és hosszabb utánkövetési idővel végzett vizsgálat szükséges. Revízió végzése ott optimális, ahol a technikai lehetőségek tárháza mind protetikai, mind a csontpótlás oldaláról elegendően széles, és az adott esethez a rendelkezésre álló lehetőségek közül a legjobbat lehet választani (25).

\section{IRODALOM}

1. Abdel M. P., Trousdale R. T., Berry D. J.: Pelvic discontinuity associated with total hip arthroplasty: Evaluation and management. J. Am. Acad. Orthop. Surg. 2017. 25. (5): 330-338. https://doi.org/10.5435/JAAOS-D-15-00260

2. Ahmed G. A., Ishaque B., Rickert M., Folsch C.: Allogene Knochentransplantation in der Hüftrevisionsendoprothetik : Indikationen und Rekonstruktionsmöglichkeiten. Orthopäde. 2018. 47. (1): 52-66. https://doi.org/10.1007/s00132-017-3506-3

3. Asaf M.: Classifications used in total hip arthroplasty. In: Bagaria V. (Eds.): Total hip replacement: An overview. London. IntechOpen Limited. 2018. 19-33. p.

4. Beckmann N. A., Weiss S., Klotz M. C., Gondan M., Jaeger S., Bitsch R. G.: Loosening after acetabular revision: comparison of trabecular metal and reinforcement rings. A systematic review. J. Arthroplasty. 2014. 29. (1): $229-235$. https://doi.org/10.1016/i.arth.2013.04.035

5. Berry D. J., Muller M. E.: Revision arthroplasty using an anti-protrusio cage for massive acetabular bone deficiency. J. Bone Joint Surg. Br. 1992. 74. (5): 711-715. https://doi.org/10.1302/0301-620X.74B5.1527119

6. Chen A. F., Hozack W. J.: Component selection in revision total hip arthroplasty. Orthop. Clin. North Am. 2014. 45. (3): 275286. $\mathrm{https://doi.org/10.1016/j.0cl.2014.03.001}$

7. Garcia-Cimbrelo E., Garcia-Rey E.: Bone defect determines acetabular revision surgery. Hip Int. 2014. 24. Suppl. 10: S33-36. https://doi.org/10.5301/hipint.5000162

8. Gombar C., Horvath G., Gality H., Sisak K., Toth K.: Comparison of minor bleeding complications using dabigatran or enoxaparin after cemented total hip arthroplasty. Arch. Orthop. Trauma Surg. 2014. 134. (4): $449-457$. https://doi.org/10.1007/s00402-014-1933-8

9. Greksa F., Kellermann P., Fiszter I., Gion K., Mécs L., Tóth K.: Csípőizületi protézis vápa komponensének cseréjével szerzett tapasztalataink. Magyar Traumatológia Ortopédia Kézsebészet Plasztikai Sebészet, 2009. 52. (4): 227-232.

10. Horas K., Arnholdt J., Steinert A. F., Hoberg M., Rudert M., Holzapfel B. M.: Acetabular defect classification in times of $3 D$ imaging and patient-specific treatment protocols. Orthopäde. 2017. 46. (2): $168-178$. https://doi.org/10.1007/s00132-016-3378-y

11. Hsu C. C., Hsu C. H., Yen S. H., Wang J. W.: Use of the Burch-Schneider cage and structural allografts in complex acetabular deficiency: 3- to 10-year follow up. Kaohsiung J. Med. Sci. 2015. 31. (10): $540-547$. https://doi.org/10.1016/i.kjms.2015.08.001

12. Ilchmann T., Franzen H., Mjoberg B., Wingstrand H.: Measurement accuracy in acetabular cup migration. A comparison of four radiologic methods versus roentgen stereophotogrammetric analysis. J. Arthroplasty. 1992. 7. (2): 121-127. https://doi.org/10.1016/0883-5403(92)90004-A

13. Kawanabe K., Akiyama H., Goto K., Maeno S., Nakamura T.: Load dispersion effects of acetabular reinforcement devices used in revision total hip arthroplasty: a simulation study using finite element analysis. J. Arthroplasty. 2011. 26. (7): 10611066. https://doi.org/10.1016/i.arth.2011.04.019

14. Lopez-Torres I. I., Sanz-Ruíz P., Sánchez-Pérez C., Andrade-Albarracin R., Vaquero J.: Clinical and radiological outcomes of trabecular metal systems and antiprotrusion cages in acetabular revision surgery with severe defects: a comparative study. Int. Orthop. 2018. 42. (8): 1811-1818. https://doi.org/10.1007/s00264-018-3801-6

15. Migaud H., Common H., Girard J., Huten D., Putman S.: Acetabular reconstruction using porous metallic material in complex revision total hip arthroplasty: A systematic review. Orthop. Traumatol. Surg. Res. 2019. 105. (1S): S53-S61. https://doi.org/10.1016/i.otsr.2018.04.030

16. National Joint Registry for England, Wales, Northern Ireland and the Isle of Man. 16th Annual Report 2019. Available from: https://reports.njircentre.org.uk/Portals/O/PDFdownloads/NJR\%2016th\%20Annual\%20Report\%202019.pdf

17. Ochs B. G., Schmid U., Rieth J., Ateschrang A., Weise K., Ochs U.: Acetabular bone reconstruction in revision arthroplasty: a comparison of freeze-dried, irradiated and chemically-treated allograft vitalised with autologous marrow versus frozen non-irradiated allograft. J. Bone Joint Surg. Br. 2008. 90. (9): 1164-1171. https://doi.org/10.1302/0301-620X.90B9.20425

18. Paprosky W. G., Bradford M. S., Younger T. I.: Classification of bone defects in failed prostheses. Chir Organi Mov. 1994;79(4): 285-291.

19. Paprosky W. G., Perona P. G., Lawrence J. M.: Acetabular defect classification and surgical reconstruction in revision arthroplasty. A 6-year follow-up evaluation. J. Arthroplasty. 1994.9 9. (1): 33-44. https://doi.org/10.1016/0883-5403(94)90135-X

20. Petrie J., Sassoon A., Haidukewych G. J.: Pelvic discontinuity: current solutions. Bone Joint J. 2013. 95-B. 11. Suppl A: 109 113. $\mathrm{https://doi.org/10.1302/0301-620X.95B11.32764}$

21. Regis D., Magnan B., Sandri A., Bartolozzi P.: Long-term results of anti-protrusion cage and massive allografts for the management of periprosthetic acetabular bone loss. J. Arthroplasty. 2008. 23. (6): 826-832. https://doi.org/10.1016/i.arth.2007.06.017 
22. Rossman S. R., Cheng E. Y.: Reconstructing pelvic discontinuity and severe acetabular bone loss in revision hip arthroplasty with a massive allograft and cage. JBJS Essent. Surg. Tech. 2016. 6. (3): e30. https://doi.org/10.2106/JBJS.ST.16.00026

23. Simon P., von Roth P., Perka C.: Treatment algorithm of acetabular periprosthetic fractures. Int. Orthop. 2015. 39. (10): 1995-2003. https://doi.org/10.1007/s00264-015-2968-3

24. Szczepanski J. R., Perriman D. M., Smith P. N.: Surgical treatment of pelvic discontinuity: a systematic review and metaanalysis. JBJS Rev. 2019. 7. (9) :e4. https://doi.org/10.2106/JBJS.RVW.18.00176

25. Tóth K., Janositz G., Kovács G.: Cement nélküli vápával végzett revíziók középtávú tapasztalatai. Magyar Traumatológia Ortopédia Kézsebészet Plasztikai Sebészet, 2009. 52. (4): 239-248.

26. Villanueva M., Rios-Luna A., Pereiro De Lamo J., Fahandez-Saddi H., Bostrom M. P.: A review of the treatment of pelvic discontinuity. HSS J. 2008. 4. (2): 128-137. https://doi.org/10.1007/s11420-008-9075-6

27. Wedemeyer C., Otte S., von Knoch M., Quint U., von Knoch F., Loer F.: Strukturelle Femurkopfallografts in der Revisionschirugie von gelockerten Hüftendoprothesenpfannen. Unfallchirurg. 2007. 110. (2): $104-110$. https://doi.org/10.1007/s00113-006-1195-1

28. Wu H., Ma C., Ran J., Xu D., Liu A., Sun M., Wu L., Yan S.: Biomechanical research on contour cage with transacetabular screws fixation in revision total hip arthroplasty. Clin. Biomech. (Bristol, Avon). 2017. 47: 117-122. https://doi.org/10.1016/i.clinbiomech.2017.06.009

29. Yu R., Hofstaetter J. G., Sullivan T., Costi K., Howie D. W., Solomon L. B.: Validity and reliability of the Paprosky acetabular defect classification. Clin. Orthop. Relat. Res. 2013. 471. (7): 2259-2265. https://doi.org/10.1007/s11999-013-2844-7

\section{Dr. Friebert Gábor}

\section{SZTE ÁOK Ortopédiai Klinika}

6725 Szeged, Semmelweis u. 6.

E-mail: frieb.gabor@gmail.com 